\title{
Formulation of Anti-Acne Gel of Moringa oleifera, $L$. Ethanolic Extract and Bacteriostatic Test on Staphylococcus epidermidis
}

\author{
Cahyarani Intan Ramadhani, Dian Eka Ermawati* \\ Fakultas MIPA, Universitas Sebelas Maret, Surakarta \\ Corresponding author: Dian Eka Ermawati: Email: dianekae@staff.uns.ac.id \\ Submitted: 02-10-2019 Revised:03-02-2020 Accepted: 12-02-2020
}

\begin{abstract}
Moringa oleifera L. leaves contain flavonoid, alkaloid, and phenolic compounds which have antibacterial activity. Staphylococcus epidermidis is one of the bacteria that causes acne. The purpose of this study is to compare bacteriostatic ability of the extracts and gel for S. epidermidis bacteria and to get gel formula that can fulfills the physical properties of a good gel. Moringa leaves were extracted with maceration method using ethanol 70\% in three days. HPMC 4000 was used as the polymer. Extract was added with variation concentrations of 5, 10, and 15\%. Physical evaluation of gel was organoleptic, homogeneity, $\mathrm{pH}$, viscosity, adhesion, and spread tests for 4 weeks. In vitro bacteriostatic activity test with 1\% clindamycin gel as positive control and polymer gel as negative control. The result showed that variations concentrations of ethanolic extract of Moringa leaves affected the physical properties of gel including viscosity, $\mathrm{pH}$, adhesion and spreadability. Bacteriostatic activity test of ethanolic extract of Moringa leaf was classified as strong activity, while $15 \%$ Moringa leaf ethanol extract gel was classified as moderate activity with average diameter was $9.14 \mathrm{~mm}$ according classification of Davis and Stout 1971.
\end{abstract}

Keywords: moringa leaves,; HPMC 4000; gel; Staphylococcus epidermidis

\section{INTRODUCTION}

Acne can be caused by bacterial activity such as Staphylococcus epidermidis [Djajadisastra, 2009]. Currently acne treatment is antibiotic therapy which has skin irritation side effects and resistance in long-term use [Wasitaatmadja, 2008]. Moringa is a shrub that used widely as a vegetable or animal feed. Moringa leaves are empirically known has an antibacterial activity, because Moringa leaves contain secondary metabolites such as flavonoids, alkaloids, and phenols [Pandev et al., 2012]. Previous research that has been carried out on ointment preparations of Moringa leaf extract showed an antibacterial activity against Propionibacterium acne [Choirunisa et al., 2017]. Ethanolic extract of Moringa leaves with concentrations 5,10 , and $15 \%$ in ointment preparations has strong inhibitory activity against Staphylococcus aureus [Djumaati et al., 2018]. This research was carried out by made a formulation of anti-acne gel using Hydroxy propyl methyl cellulose (HPMC) as polymer and ethanol extract of Moringa leaf for acne treatment. Gel has better potential topical drug facilities than ointments, because gel is not sticky, requires less energy for formulation, more stable, and has good aesthetic value.
Another advantage of gel preparation is quickly absorbed, so it is more effective to help absorbtion of active ingredient in acne area. Ethanolic extract of Moringa leaves gel with HPMC as a polymers has activity to inhibit Malassezia furfur [Yusuf et al., 2017].

This study was carried out using a variation concentration 5,10 , and $15 \%$ of ethanolic extract of Moringa oleifera leaves and formulated in to anti-acne gel with HPMC polymers. Ethanolic extract of Moringa oleifera leaves and gel preparation were determine their bacteriostatic activity compare with clindamycin 1\% gel. Variation concentration of extract was also carried out to obtain the most effective gel formula against Staphylococcus epidermidis bacteria, as well as physical properties test including, organoleptic test, homogeneity test, $\mathrm{pH}$, viscosity, adhesion, and spreadability test.

\section{METHOD}

Tools

Glassware (Pyrex), analytical weight scales (PRECISA-XB 620C), rotary evaporator (STUART-RE300DB), pH meter (OHAUSSTARTER300), viskometer (RION-VT-04), moisture analyzer (OHAUS-MB25), incubator 
Formulation of Anti-Acne Gel of Moringa oleifera, L. Ethanolic Extract

Table I. Gel Formula of Etanolic Extract of Moringa oleifera L. Leaves

\begin{tabular}{lcccc}
\hline \multirow{2}{*}{\multicolumn{1}{c}{ Ingredients }} & \multicolumn{4}{c}{ Gel Formulae (g) } \\
\cline { 2 - 5 } & F1 & F2 & F3 & KN \\
\hline Moringa Leaves Extract & 5.0 & 10.0 & 15.0 & - \\
HPMC & 1.5 & 1.5 & 1.50 & 1.50 \\
Propylen Glycol & 12.0 & 12.0 & 12.0 & 12.0 \\
Methyl paraben & 0.10 & 0.10 & 0.10 & 0.10 \\
Aquadest & 81.40 & 76.40 & 71.40 & 86.40 \\
\hline
\end{tabular}

F1 : Antiacne gel formula with 5\% etanolic extract of moringa leaves; F2 : Antiacne gel formula with $10 \%$ etanolic extract of moringa leaves; F3 : Antiacne gel formula with 15\% etanolic extract of moringa leaves; KN : Gel Formula as negative control

(OH) MEMMERT-UNB 400), autoclaves (HIRAYAMA-HVE-5), and other supporting tools.

\section{Material}

Moringa leaf, Hydroxy Propyl Methyl Cellulose 4000 M (Tianpu Chemicals Co. Ltd.), propylene glycol (Dow Chemical Pacific), methyl paraben (Ueno Fine Chemicals Industry Ltd.), 70\% ethanol (Medica), Muller Hinton Agar Media (Oxoid), Mc Farland standard 0.5 (Remel), clindamycin $1 \%$ gel, and Staphylococcus epidermidis bacteria ATCC 12228.

\section{Method}

Extraction of Moringa leaves

Moringa oleifera L. extract was made using maceration method. Maceration used 70\% ethanol as solvent in ratio (1: 7.5). Extraction was carried out by weighing 600 grams of Moringa leaf powder then transferred to a maceration vessel with $4500 \mathrm{~mL}$ of $70 \%$ ethanol, then stirred and closed. Solution were left for 24 hours and occasionally shaken at least 3 times.

\section{Phytochemical Detection}

Phytochemical detection in ethanolic extract of Moringa oleifera L. leaves was carried out by using TLC (Thin Layer Chromatography) method. Sample preparation was carried out by dissolving $300 \mathrm{mg}$ ethanolic extract of Moringa oleifera L. in $10.0 \mathrm{~mL}$ ethanol $70 \%$, then spotted in the stationary phase of GF-254 silica gel with $5 \mu \mathrm{L}$ spot volume of extract, mobile phase is used chloroform: ethyl acetate (2: 1) and eluted 8.0 $\mathrm{cm}$ range in a saturated chamber that eluted with filter paper before. TLC results can be seen by looking at the spots in visible light, UV 254 $\mathrm{nm}$, and UV $366 \mathrm{~nm}$ and calculate the Rf (Retention factor) value, then $\mathrm{Rf}$ value of chemical compounds was identified with standard Rf of chemical components, and can be ascertained using spray reagents.

\section{Formula Design of Antiacne Gel}

Design of Antiacne gel formula was carried out by determine HPMC consentration as a polymer that suitable with the characteristics ethanolic extract of Moringa leaves. Formula used to make anti-acne gel preparations can be seen in Table I.

Antiacne gel of ethanolic extract Moringa leaves were made by swelling HPMC into hot aquadest 20 times HPMC weight in 15 minutes. Methyl paraben wes dissolved in propylen glycol and stirred, this solution poured into HPMC solution then stirred untill homogen. Aquadest was added untill form a gel base. Ethanolic extract of Moringa leaves were added to gel base and stirred untill homogen.

\section{Physical Evaluation of Antiacne Gel}

Physical evaluation of etanolic extract Moringa leaves antiacne gel includes organoleptic, homogeneity, viskosity, $\mathrm{pH}$, adhesive, spreadability test and stability test. Stability test were obtained in initial week until $4^{\text {th }}$ week each test were replicated in 3 times.

\section{Organoleptic test}

Organoleptic test was carried out by describing shape, colour, smell, and texture of the gel. Organoleptic test were evaluated every week in 4 weeks.

\section{Viscosity test}

Viscosity test was carried out by using viscometer Rion VT-04. Sample tube was filled 
by gel sample, rotor was placed in the middle of the sample tube until the spindle was submerged into the gel, viscometer was turned on and rotor will rotated, rotor pointing needle will automatically move, viscosity were measured by read the $2^{\text {nd }}$ rotor scale.

pH test

$\mathrm{pH}$ test was carried out by using $\mathrm{pH}$ meter. Sample preparation was carried out by weighing $1.0 \mathrm{~g}$ gel then dissolved into $10 \mathrm{~mL}$ aquadest. Electrode was dipped to the sample solution, then read button was pressed untill $\mathrm{pH}$ value was constant. $\mathrm{pH}$ test was did at room temperature.

\section{Spreadability test}

Amount of $0.5 \mathrm{~g}$ gel were placed on petri disc and closed with other petri disc, and wait untill 1 minute, spread diameter of the gel were measured from vertical and horizontal side. 50 , 100 , and $150 \mathrm{~g}$ load were added on the petri disc and left for 1 minute, then diameter of the gel was measured. Load were added untill make a constan diameter or gel cannot spread anymore.

\section{Stickiness test}

Amount of $0.5 \mathrm{~g}$ gel were placed on object glass and were closed with another object glass. Object glass were placed into adhesive test tool, and place $80 \mathrm{~g}$ of load, Stickiness test of gel was measured by counting time for object glass to break each other.

\section{Ethanolic Extract of Moringa Leaves Bacteriostatic Activity to Staphylococcus epidermidis}

Antibacterial activity was carried out by disc diffusion method (Kirby-Bauer test), sterile cotton swab dipped into the Staphylococcus epidermidis bacterial suspension, then rotated several times and pressed to the tube wall to remove excessive inoculum in cotton swab. Staphylococcus epidermidis were inoculated into agar media. Paper disc (6 $\mathrm{mm}$ ) were dipped in sample (gel preparations F1, F2, F3, and ethanolic extract of Moringa leaves 5, 10, and $15 \%$ ) then the paper disc were placed on the surface of the media, position of each paper disc was 2-3 cm from the edge of petri dish. Positig.4. control was used $1 \%$ clindamycin gel, and negative control was used HPMC polymer and water. Petri dish were incubated at $37^{\circ} \mathrm{C}$ for 24 hours and then the diameter of inhibition zone were observed.

\section{RESULT AND DISCUSSION Determination of Plant}

Moringa leaves used in this study were from Ngadirojo, Wonogiri. Determinaton of the plant were observed in Biology Laboratory, Matemathic and Science Faculty, Universitas Sebelas Maret, Surakarta. Result of the determinaton showed that the plant used in this study was Moringa plant (Moringa oleifera L.).

\section{Extraction and Extract Evaluation}

Moringa leaves were maserated using polar solvent to extract polar molecule (saponin, tannin, and flavonoid). Ethanolic extract of Moringa leaves were brownish-green, smells herbally, and has very viscous consistency. Sample were produced 135.96 g (22.66\%) of extract. Active compound of Moringa leaves were fit to the criteria minimum standard of yield, it was above 10\% [Hasanah et al., 2016]. Addhesive test of ethanolic extract of Moringa leaves was purposed to know consistency level of ethanolic extract of Moringa leaves. Result means of addhesive test of ethanolic extract of Moringa leaves was $1.14 \pm 0.03$ minute, it means that adhesive time of this extract was long. and the extract of Moringa leaves has very viscous consistency. Water content of ethanolic extract of Moringa leaves was 2.59\%. Water content of extract criteria was <10\% [Depkes RI, 1995], so water content of ethanolic extract of Moringa leaves still fit to the criteria.

\section{Phytochemical Detection}

Phytochemical detection was carried out to know the group of active compounds into ethanolic extract of Moringa leaves, TLC (Thin Layer Chromatography) method was used in this study. Sample was eluted then sprayed with reagents.

Phytochemical identification of ethanolic extract of Moringa leaves can be seen in Table II. Colour change of the spot showed phenolic, flavonoid, and alkaloid compound in the ethanolic extract of Moringa leaves.

\section{Physical Evaluation of Gel Ethanolic Extract of Moringa Leaves}

Physical evaluation was carried in orde to know the differences between formulas and 
Table II. Phytochemical Identification ethanolic extract of Moringa leaves spray ingreagents

\begin{tabular}{lll}
\hline Reagents & Spot colour & \multicolumn{1}{c}{ Compound } \\
\hline $\mathrm{FeCl}_{3}$ & Blackish green & Phenolic \\
Wagner & Brown & Alkaloid \\
Citroboric & Yellow fluorescent at UV 366 nm & Flavonoid \\
Lieberman-Burchard & - & - \\
\hline
\end{tabular}
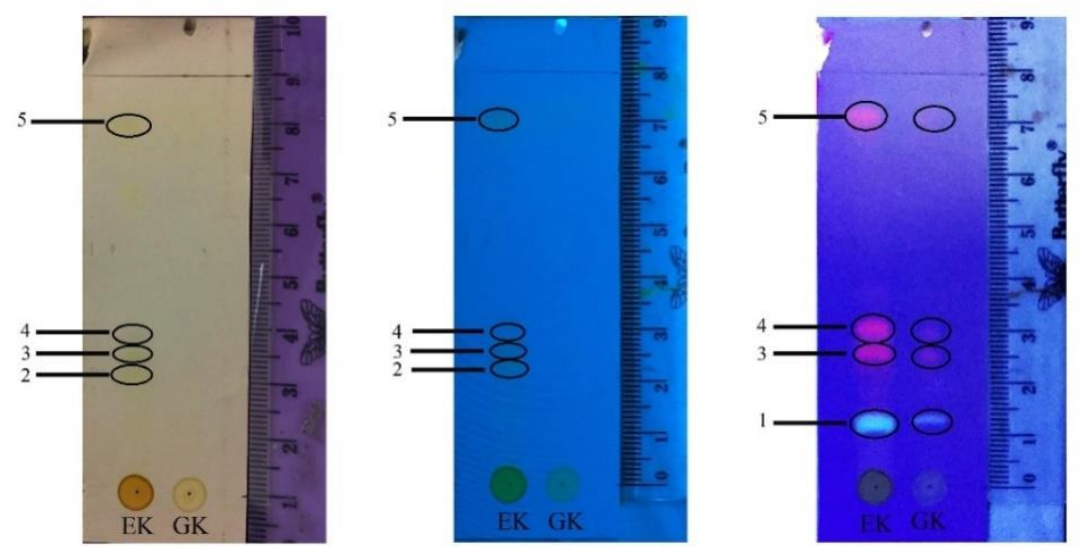

Figure 1. TLC Result of ethanolic extract of Moringa leaves (EK) dan Gel of ethanolic extract of Moringa leaves (GK) with Stationary phase was Silica Gel GF 254 and eluent was chloroform: Ethyl Asetate (2:1) At Visible Light (a), UV $254 \mathrm{~nm}$ (b), dan UV 366 nm (c)

to know suitability between observation with standard criteria. Physical stability test of gel were purposed to know stability of gel formula after 4 week stored in room temperature. Physical evaluation of gel observed organoleptic, $\mathrm{pH}$, viscosity, spreadability, and adhesive test. Result of physical evaluation in initial week can be seen in Table III.

\section{Organoleptic test}

Gel organoleptic result in initial week can be seen in Table III. Formula 1 and 2 has brownish colour but formula 3 has darker brown colour, it can caused by higher extract consentration. Gel of Moringa Leaves ethanolic extract also produce higher consistency in formula 3 , because of higher consentration of Moringa leaves ethanolic extract. All formula produce same smell of Moringa leaves ethanolic extract. Result study showed various extract consentration can influences its organoleptic properties.

Organoleptic test result after 4 week stored (Table IV), showed there were no difference in formula 1 for all parameter. Consistency parameter for formula 2 and 3 has produce different result, its consistency had changed in week-2 untill week-4. Formula that can produce better organoleptic stability was formula 1 with Moringa leaves ethanolic extract was $5 \%$.

pH Test

$\mathrm{pH}$ test was purposed to know the safety of the preparation when used on skin. Topical preparation $\mathrm{pH}$ must fit to topical skin $\mathrm{pH}$ (4.56.5), so it could not make skin iritation [Naibaho et al., 2013]. pH gel in initial week showed in table III, $\mathrm{pH}$ value of formula 1 was 5.83; formula 2 was 5.75; and formula 3 was 5.72. All formula has fit to the $\mathrm{pH}$ skin criteria, so it is safe to use.

$\mathrm{pH}$ gel result in initial week were analyzed with One Way Anova and produced $p$ value $=0.00(<0.05)$ it means that formula were significantly different caused of variation consentration of extract. Post Hoc analysis result produced $p$-value $=0.00$, it means that consentration variation of extract has affect $\mathrm{pH}$ value of gel preparation.

$\mathrm{pH}$ value was decrease after stored, it means gel were more acidic, it can caused by temperature and condition of storage [Padmadisastra, 2007]. However all formula still fit to the criteria of normal skin $\mathrm{pH}(4.5-7)$. Duration of storage $\mathrm{pH}$ value of gel preparation, 


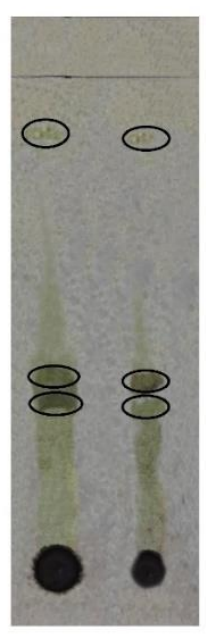

(a)

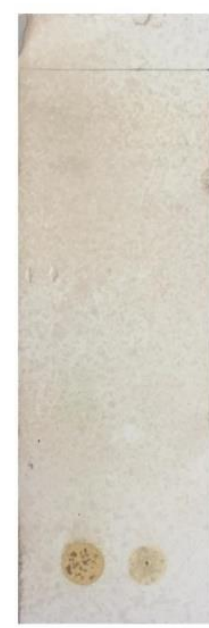

(b)

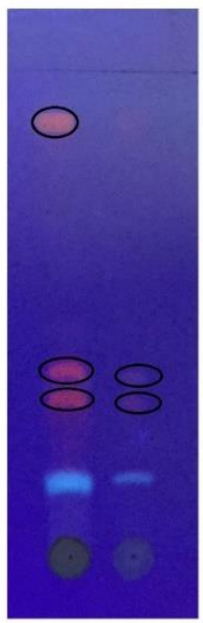

(c)

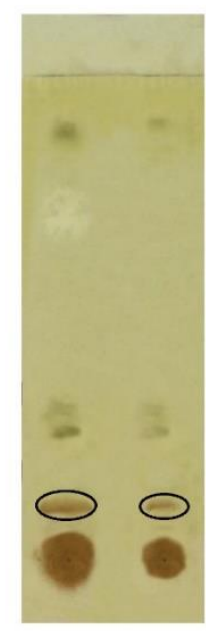

(d)

Figure 2. Compound Identification Result Using Spray Reagent to Make Colour Change to Spot in TLC Ethanolic Extract of Moringa Leaves (EK) and Gel of Ethanolic extract of Moringa Leaves (GK) Using $\mathrm{FeCl}_{3}$ (a), Lieberman-Burchard (b), Citroboric (c), Wagner (d)

Table III. Physical Evaluation of Gel Ethanolic Extract of Moringa Leaves Initial Week

\begin{tabular}{llccc}
\hline & \multirow{2}{*}{ Parameter } & \multicolumn{3}{c}{ Observation } \\
\cline { 2 - 5 } & Colour & F1 & F2 & F3 \\
\hline Organoleptic & Smell & + & + & ++ \\
& Consistency & + & + & + \\
& & + & + & + \\
Homogeneity & & Homogen & Homogen & Homogen \\
pH & & $5.83 \pm 0.01$ & $5.75 \pm 0.01$ & $5.72 \pm 0.01$ \\
Viscosity (dPa.s) & $900 \pm 0.00$ & $1000 \pm 0.00$ & $1100 \pm 0.00$ \\
Addhesive (sec) & $3.78 \pm 1.62$ & $4.43 \pm 0.22$ & $5.36 \pm 0.01$ \\
Spreadability (cm) & & $5.00 \pm 0.04$ & $4.70 \pm 0.03$ & $4.50 \pm 0.03$ \\
\hline
\end{tabular}

F1 : Antiacne gel formula with $5 \%$ etanolic extract of moringa leaves; F2 : Antiacne gel formula with $10 \%$ etanolic extract of moringa leaves; F3 : Antiacne gel formula with $15 \%$ etanolic extract of moringa leaves; KN : Gel Formula as negative control

Explanation: Colour + : Brown; Colour ++ : Dark Brown; Smell + : Typically Moringa Leaves Extract Smells; Consistency + : Viscous; Consitency ++ : Very viscous

it means that all formulas are unstable in storage.

\section{Viscosity Test}

Viscosity expressed resistence of liquid to flow. Viscosity value in initial week can be seen in table III. Viscosity value of formula 1 was 900 dPa.s (90 Pa.s), formula 2 was 1000 dPa.s (100 Pa.s) and formula 3 was 1100 dPa.s (110 Pa.s). it means that variation concentration of extract affected its viscosity. Viscosity criteria standard for gel was 6000-50000 cP (6-50 Pa.S) based on SNI 16-4399-1996 [Hidayanti et al., 2015], it means all viscosity value still not fit to the criteria.

Viscosity of gel evaluation result in 4 week stored can be seen in figure 2 . Viscosity level of formula 1 in initial week untill week-4 were in range of 850-900 dPa.s it means that there were no significant change in viscosity, however there were significant change in formula 2 and 3 . Viscosity were decrease because of Moringa leaves ethanolic extract had acidic $\mathrm{pH}$. HPMC polymer were basic polymer, so HPMC polymer were hydrolyzed in acidic $\mathrm{pH}$, it caused change of gel viscosity to a more 

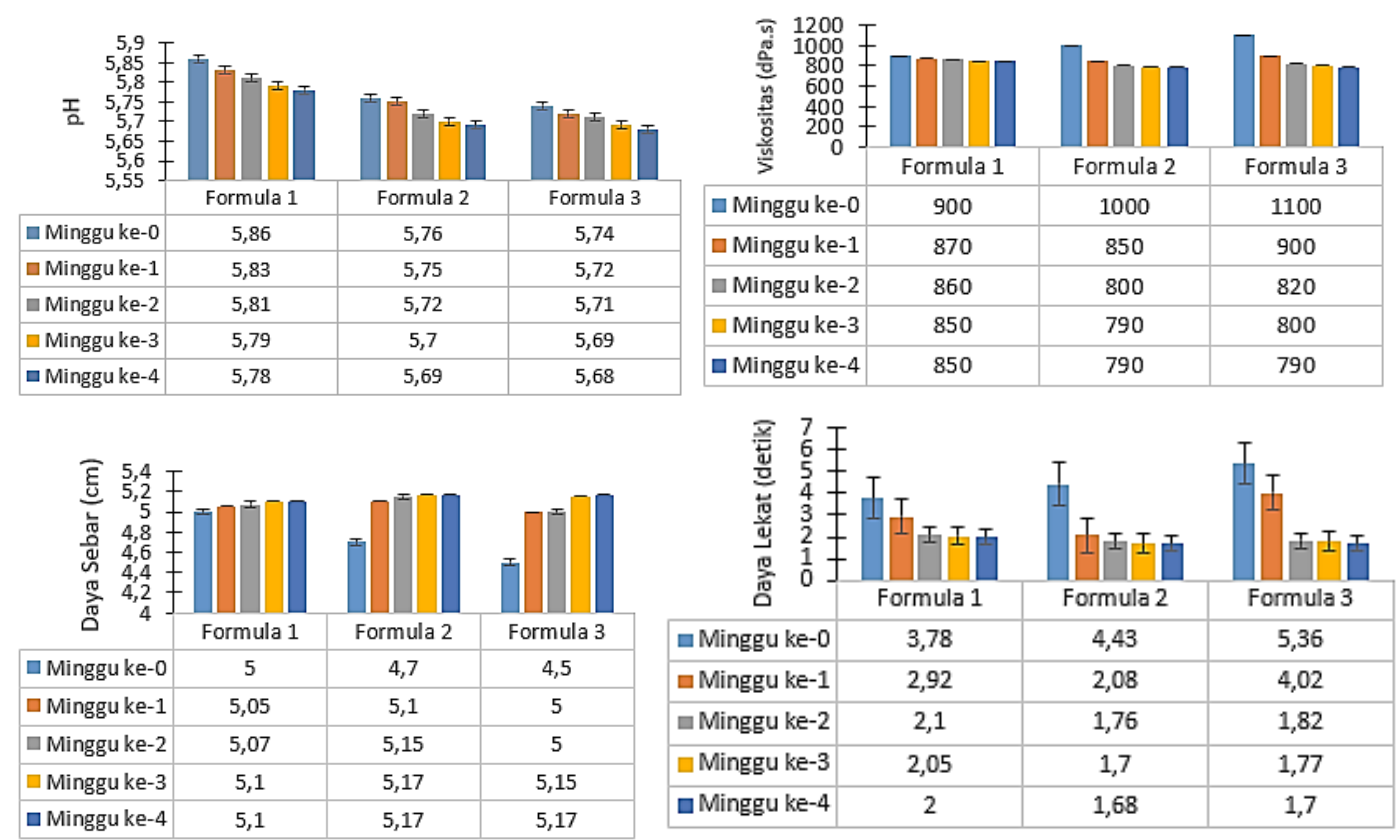

Figure 3. The chart result of Physical Evaluation of Gel of Moringa Leaves Ethanolic Extract in 4 week, involved $\mathrm{pH}$, Viscosity, Spreadability and Addhesive test

Table IV. Organoleptic Study of Gel of Moringa Leaves Ethanolic Extract in 4 Weeks

\begin{tabular}{lcccccc}
\hline \multirow{2}{*}{ Observation Parameter } & \multirow{2}{*}{ Formula } & \multicolumn{5}{c}{ Week } \\
\cline { 3 - 6 } Colour & & $\mathbf{0}$ & $\mathbf{1}$ & $\mathbf{2}$ & $\mathbf{3}$ & $\mathbf{4}$ \\
& F1 & - & - & - & - & - \\
\multirow{3}{*}{ Smell } & F3 & - & - & - & - & - \\
& F1 & - & - & - & - & - \\
\multirow{3}{*}{ Consistency } & F2 & - & - & - & - & - \\
& F3 & - & - & - & - & - \\
& F1 & - & - & - & - & - \\
& F2 & - & - & + & + & + \\
\end{tabular}

aqueous form (Astuti et al., 2012). Stored duration can affect gel viscosity in formula 2 and 3 , but non-significantly affect viscosity in formula 1.

\section{Adhesion Test}

Adhesion gel more greater, absorbtion of active substance also can be greater, due to longer interaction of gel with skin, so gel base will release more active substance. Results of adhesive test for gel of Moringa leaves ethanolic extract in initial week can be seen in table III. Adhesive value of formula 3 was 5.36 seconds, it was the highest adhesive value, adhesive value of formula 2 was 4.43 seconds and formula 1 was 3.78 seconds. Adhesion value criteria for topical preparations is not less than 4 seconds [Ulaen et al., 2012]. Formula 2 and 3 were fit to the criteria of good adhesion value. Variation concentration of extract were affected adhesion value of anti-acne gel. One Way Anova analysis of adhesion test in initial week produced $p$-value = $0.53(>0.05)$ it means that variation concentration of extract has non-significantly different adhesion value. Variation concentration of extract was non-significantly affect the adhesion value.

Adhesion value was decrease in 4 week stored, it can caused by unstable temperature and acidic effect of extract that caused 


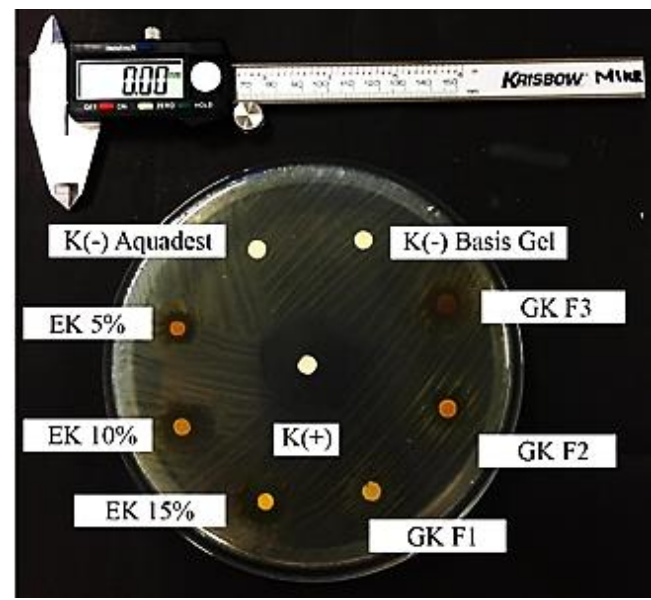

Figure 4. Inhibition Zone of Antiacne Gel (GK), Ethanolic Exract of Moringa Leaves (EK), Negative Control (K(-)),and Positive Control $(\mathrm{K}(+))$ to Staphylococcus epidermidis in MHA Medium

Table IV. Inhibition zone of Antiacne Gel to Staphylococcus epidermidis

\begin{tabular}{cccccc}
\hline & \multicolumn{4}{c}{ Inhibition Zone Diameter (mm) } & $\begin{array}{c}\text { Antibacterial } \\
\text { Activity }\end{array}$ \\
\cline { 2 - 5 } & Replication & Replication 2 & Replication 3 & Mean & - \\
K1 (-) & - & - & - & - & - \\
K2 (-) & - & - & - & - & Very Strong \\
K (+) & 31.35 & 32.29 & 32.82 & $32.15 \pm 0.74$ & Moderate \\
EK 5\% & 6.89 & 5.23 & 7.54 & $6.55 \pm 1.19$ & Strong \\
EK 10 \% & 11.62 & 10.87 & 9.54 & $10.68 \pm 1.05$ & Strong \\
EK 15 \% & 19.18 & 19.53 & 19.70 & $19.47 \pm 0.27$ & Moderate \\
GK F1 & 4.89 & 4.98 & 5.38 & $5.08 \pm 0.26$ & Moderate \\
GK F2 & 5.87 & 6.47 & 5.72 & $6.02 \pm 0.40$ & Moderate \\
GK F3 & 8.82 & 9.44 & 9.15 & $9.14 \pm 0.31$ & \\
\hline
\end{tabular}

unstability of HPMC as polymer. Adhesion time was directly proportional with viscosity, lower viscosity, will also produce lower adhesion time [Astuti et al., 2012]. Adhesion value result of his study showed that gel formulation were unstable while stored.

\section{Spreadability Test}

Gel preparation are expected to be easily spread on the skin without significant pressure, more great contact of gel with the skin surface area, will be more easy for gel to be applied, it means gel can distributed equally on skin [Windriyatri et al., 2007]. Good gel dispersion is between 5-7 cm [Grag, 2002]. Spreadability test in initial week (Table III), showed that formula 1 fit to the criteria of good spreadability value, it was $5.00 \mathrm{~cm}$, formula 2 and 3 did not fit the criteria of good spreadability value it was 4.70 $\mathrm{cm}$ and $4.50 \mathrm{~cm}$.

One Way Anova test of spreadability test in initial week produced a significant $\mathrm{p}$-value =
$0.00(<0.05)$ it means that in there were a significant difference in the spreadability value due to variation concentration of extract. Post Hoc test results showed a significant differences of spreadability value in all formula ( $p$-value $=$ $0.00)$. It can be concluded that variation concentration of ethanolic extract affected the spreadability value. Spreadability value in 4 week stored result showed in figure 4. All formula were increase its spreadability value every week, it can caused by consistency change. Lower viscosity of gel after stored caused higher fluid flow. Formula 1 produce better stability of spreadability value than formula 2 and 3 after 4 weeks stored in room temperature.

\section{Antibacterial Activity}

Antibacterial activity of gel antiacne gel has inhibition zone diameter mean $5.08 \mathrm{~mm}$ for formula 1, formula 2 was $6.02 \mathrm{~mm}$, and formula 3 was $9.14 \mathrm{~mm}$, all formula were included moderate inhibition category [Davis and Stout, 
1971]. Positive control (Clindamycin gel 1\%) showed inhibition zone diameter was $32.15 \mathrm{~mm}$, it was included very strong inhibition category and there was no inhibition zone in negative control. Higher inhibition zone was formula 3, it caused by ethanolic extract consentration was higher than other formula (15\%).

Consentration variation of Moringa leaves ethanolic extract $(5,10$, and 15\%) affected Staphylococcus epidermidis inhibition, higher consentration of Moringa leaves ethanolic extract will also higher antibacterial activity, because of higher ethanolic extract also has higher chemical compound that inhibit bacterial growth. Inhibition zone diameter gel contain variation consentration of extract $(5,10$, dan $15 \%$ ) showed that was not aligned with inhibition zone diameter in ethanolic extract of Moringa leaves. It may caused by gel polymer holding the active substance released, because gel polymer was usually used to extend the effect of active components, so it was affect in efectivity of Moringa leaves ethanolic extract.

\section{KESIMPULAN}

Higher consentration of Moringa leaves ethanolic extract produce higher activity antibacterial with higher inhibition zone diameter to Staphylococcus epidermidis. Antiacne gel of Moringa leaves ethanolic extract has antibacterial activity to Staphylococcus epidermidis with moderate inhibition category, better formula for antibacterial activity was formula 3 with consentration of Moringa leaves ethanolic extract was $15 \%$ and fulfill the best gel physical properties.

\section{DAFTAR PUSTAKA}

Apriana, R., Rahmawanty, D. dan Fitriana, M., 2017, Formulasi Dan Uji StabilitasGelAntijerawat yang Mengandung Kuersetin Serta Uji Efektivitas Terhadap Staphylococcus epidermidis. Jurnal Pharmascience, 4(2): 187-201.

Astuti, D. D., 2012, Formulasi Sediaan Gel Ekstrak Etanolik Buah Mahkota Dewa (Phaleria macrocarpa (Scheff.) Boerl.) dengan Basis HPMC, Naskah Publikasi, Fakultas Farmasi, Universitas Muhamadiyah Surakarta, Surakarta, Hal.7-12.

Chairunnisa, A., 2017, Efektivitas Gel Ekstrak Etanol 70\% Daun Kelor (Moringa oleifera) Terhadap Propionibacterium acnes, Jurnal Pharmaceutical and Traditional Medicine, 1(2): 101-105

Davis, W. W. and Stout, T. R., 1971, Disc Plate Method of Microbiological Antibiotic Assay, Applied Microbiology, 22(4): 659665.

Depkes RI., 1995, Materia Medika Indonesia. Jilid VI. Jakarta: Departemen Kesehatan Republik Indonesia.

Djajadisastra, J., Mun'im, A., \& NP, D., 2009, Formulasi Gel Topikal dari Ekstrak Nerii folium dalam Sediaan Anti Jerawat, JFI Online, 4(4): 210-216.

Djumaati, F., Yamlean, P. V. Y., \& Lolo, W. A., 2018, Formulasi Sediaan Salep Ekstrak Etanol Daun Kelor (Moringa Oleifera Lamk.) dan Uji Aktivitas Antibakterinya Terhadap Bakteri Staphylococcus aureus, Pharmacon, 7(1): 22-29.

Grag, A., 2002, Spreading of Semisolid Formulation : An Update, Pharmaceutical Technology, p.84-102

Hasanah, N., Susilo, J. dan Oktianti, D., 2016, Uji Aktivitas Antioksidan Ekstrak Etanol Daun Kelor (Moringa oleifera Lamk) dengan Metode DPPH, Jurnal Gizi dan Kesehatan, 8: 17.

Hidayanti. U.W., Fadraersada,J., Ibrahim, A. 2015. Formulasi Dan Optimasi Basis Gel Carbopol 940 Dengan Berbagai Variasi Konsentrasi. Prosiding Seminar Nasional Kefarmasian Ke-1. Hal.68-75.

Kuncari, E.S., Iskandarsyah, I. dan Praptiwi, P., 2014, Evaluasi, Uji Stabilitas Fisik dan Sineresis Sediaan Gel yang Mengandung Minoksidil, Apigenin dan Perasan Herba Seledri (Apium graveolens L.). Buletin Penelitian Kesehatan, 42(4): 213-222.

Naibaho, O.H., Yamlean, P.V., \& Wiyono, W., 2013, Pengaruh Basis Salep Terhadap Formulasi Sediaan Salep Ekstrak Daun Kemangi (Ocimum sanctum L.) Pada Kulit Punggung Kelinci yang Dibuat Infeksi Staphylococcus aureus, Pharmacon, 2(2): 27-33.

Padmadisastra, 2007, Formulasi Sediaan Salep Antikeloidal yang Mengandung Ekstrak Terfasilitasi Panas Microwave dari Herba Pegagan (Centella asiatica (L.)Urban), dalam Seminar Kebudayaan Indonesia Malaysia Kuala lumpur 2007, Bandung, Fakultas Farmasi, Universitas Padjadjaran, Hal.1-11. 
Pandey, A., Pandey, R. D., Tripathi, P., Gupta, P. P., Haider, J., Bhatt, S., \& Singh, A.V., 2012, Moringa Oleifera Lam. Sahijan)-A Plant with a Plethora of Diverse Therapeutic Benefits: An Updated Retrospection, Medicinal and Aromatic Plants, 1(1): 1-8.

Ulaen, Selfie P.J., Banne, Yos Suatan \& Ririn A,. 2012. Pembuatan Salep Anti Jerawat dari Ekstrak Rimpang Temulawak (Curcuma xanthorrhiza Roxb.). Jurnal Ilmiah Farmasi. 3(2): 45-49.

Wasitaatmadja, S. M., 2008, Penuntut Ilmu Kosmetik Medik, Jakarta: Universitas
Indonesia Press, Hal.24.

Windriyati, Y.N., Wahyuningrum, D.P. dan Murrukmihadi, M., 2007, Pengaruh Perbedaan Konsentrasi Ekstrak Etanolik Umbi Bengkuang (Pachyrrhizus erosus, Urb) Dalam Sediaan Krim Terhadap Sifat Fisiknya, Jurnal Ilmu Farmasi dan Farmasi Klinik Vol, 4(1): 1.

Yusuf, A. L., Nurawaliah, E., \& Harun, N., 2017, Uji Efektivitas Gel Ekstrak Etanol Daun Kelor (Moringa oleifera L.) Sebagai Antijamur Malassezia furfur, Jurnal Ilmiah Farmasi, (2): 62-67. 